\title{
Earnings dan Liquidity sebagai Prediktor Kepailitan Bank Perkreditan Rakyat di Indonesia
}

\author{
Hesti Budiwati \\ Program Studi Manajemen STIE Widya Gama Lumajang \\ Lumajang, Jawa Timur, 67314 \\ E-mail:_hestibudiwati1404@gmail.com
}

\begin{abstract}
ABSTRAK
Salah satu ukuran untuk dapat bertahan hidup dan menjaga keberlanjutan suatu bank adalah kemampuan meraih keuntungan, Ketidakmampuan mendapatkan keuntungan dapat menjadi ancaman kepailitan bagi bank. Penelitian ini bertujuan membentuk model prediksi kepailitan Bank Perkreditan Rakyat pada variasi waktu 1 triwulan (MP1), 2 triwulan (MP2), 4 triwulan (MP4) dan 8 triwulan (MP8) sebelum pailit. Variabel prediktor adalah earnings dan liquidity yaitu ROA, ROE, BOPO, NIM dan LDR, dan variabel terikat adalah pailit dan tidak pailit. Metode analisis menggunakan regresi logistik dilanjutkan pengujian akurasi model. Populasi penelitian Bank Perkreditan Rakyat di Indonesia. Sampel sebanyak 229 Bank Perkreditan Rakyat terdiri dari 29 Bank Perkreditan Rakyat pailit dan 200 Bank Perkreditan Rakyat tidak pailit menggunakan laporan publikasi keuangan periode 2006 sampai 2017. Hasil penelitian menunjukkan dari keempat model prediksi, MP4 paling layak dan akurat sebagai model prediksi kepailitan Bank Perkreditan Rakyat yang dibentuk dari rasio ROA dan LDR. Pada tataran permodelan dengan cut off point 0,20 , MP4 memiliki akurasi $89,2 \%$ dan tataran validasi dengan cut off point 0,09 MP41 memiliki akurasi 91,74\% serta secara individu maupun serentak berpengaruh signifikan terhadap kepailitan. Berdasarkan keunggulan itu maka MP4 dipilih sebagai model yang mampu memprediksi peluang kepailitan Bank Perkreditan Rakyat di Indonesia.
\end{abstract}

Kata Kunci : Bank Perkreditan Rakyat; Earnings; Kepailitan; Liquidity

\begin{abstract}
One of the measures to survive and maintaining the sustainability of a bank is the ability to make profits, the inability to get profits can be a bankruptcy threat to a bank. The study aims to form a prediction model for rural banks bankruptcy at time variations of 1 quarter (MP1), 2 quarters (MP2), 4 quarters (MP4) and 8 quarters (MP8) before bankruptcy. The predictor variables are earnings and liquidity, namely ROA, ROE, BOPO, NIM and LDR. The dependent variables are bankrupt and non-bankrupt. The analysis method using logistic regression continued by testing the model accuration. The research population are rural banks in Indonesia. The sample of 229 rural banks consist of 29 bankrupt rural banks and 200 non-bankrupt rural banks. The data used are quarterly financial reports of 2006 to 2017. The results showed the four of prediction models, the MP4 is the most feasible and accurate as a model prediction of rural banks bankruptcy formed by ROA and LDR ratio. At the level of modelling with 0.20 cut off point, the MP4 has $89.2 \%$ accuration and level of validation with 0.09 cut off point, the MP4 has $91.74 \%$ accuration and has a significant effect on bankruptcy. Based on these advantages, the MP4 was chosen as a prediction model that able to predict the chances of bankruptcy on rural banks in Indonesia.
\end{abstract}

Keywords: Bankruptcy; Earnings; Rural Banks; Liquidity 


\section{PENDAHULUAN}

Keunggulan dalam bersaing antar perusahaan diantaranya bisa ditunjukkan dengan kemampuan menghasilkan laba yang stabil. Perusahaan yang mampu meraih laba dengan stabil maka akan mampu menjaga sustainability nya dengan baik. Keberlangsungan hidup bagi suatu perusahaan sangat penting apalagi ditengan kondisi persaingan yang tidak semakin ringan saat ini. Tidak luput juga dibidang perbankan, bermunculannya lembaga lembaga keuangan non bank menjadi tantangan tersendiri bagi lembaga keuangan perbankan karena bidang usahanya yang hamper sama yaitu menghimpun dan menyalurkan dana masyarakat. Di perbankan Indonesia ada jenis Bank Perkreditan Rakyat yang berbeda dengan jenis bank umum dalam segi kegiatan operasionalnya. Bank Perkreditan Rakyat yang relatif lebih terbatas ruang lingkupnya dibandingkan dengan bank umum tentu merupakan tantangan tersendiri bagi Bank Perkreditan Rakyat karena disamping harus bersaing dengan bank umum, dengan bank sejenis, Bank Perkreditan Rakyat juga harus bersaing dengan lembaga keuangan non bank lainnya.

Disamping dihadapkan pada kemampuan untuk menghasilkan laba dengan stabil, perbankan juga harus mampu menjaga likuiditasnya jika tidak ingin kehilangan kepercayaan dar masyarakat atau nasabahnya. Bank Perkreditan Rakyat dituntut juga mampu menjaga likuiditasnya atau mampu mebayar kewajibannya kepada nasabah atau deposan. Oleh karena itu perbankan dalam hal ini Bank Perkreditan Rakyat juga harus memiliki kemampuan memperoleh laba dan kemampuan menjaga likuiditasnya yang berkelanjutan. Jika kemampuan ini tidak dimiliki maka bukan tidak mungkin akan berujung pada kondisi bermasalah yang pada akhirnya bisa berakhir pada kepailitan.

Kemampuan menghasilkan laba yang dalam penelitian ini disebut dengan earnings dan kemampuan likuiditas yang disebut dengan liquidity, akan digunakan sebagai tool untuk memprediksi kepailitan pada Bank Perkreditan Rakyat. Earnings dan Liquidity yang digunakan merujuk pada PBI nomor 6/10/PBI/2004 tanggal 12 April 2004 dan SE Bank Indonesia nomor 6/23/DPNP tanggal 31 Mei 2004 tentang sistem penilaian tingkat kesehatan bank umum. Penelitian ini hanya mengambil earnings dan liquidity sebagai variabel prediktor dengan pertimbangan bahwa untuk mendapatkan keunggulan bersaing diperlukan kemampuan menghasilkan laba yang diwakili dengan earnings, serta pertimbangan liquidity karena disamping harus mampu menyalurkan kredit ke masyarakat BPR juga dihadapkan pada kemampuan untuk memenuhi kewajibannya pada pihak ketiga.

Studi empiris tentang kepailitan bank dilakukan oleh Martin (1977) dilakukan terhadap 5.700 bank anggota Federal Reserve System di USA dengan teridentifikasi 58 bank 
gagal pada periode penelitian 1970-1976, dengan tujuan estimasi probabilitas ketidaksehatan bank. Menggunakan rasio keuangan yang diklasifikasikan dalam 4 (empat) grup rasio asset beresiko, likuiditas, kecukupan modal dan earnings. Hasilnya kualitas asset dan kecukupan modal membentuk model terbaik dengan akurasi 82,6-96,2\%. Selanjutnya di Indonesia, Abdul Mongid (2000) meneliti dengan tujuan membentuk model prediksi menggunakan analisis logit yang diterapkan pada kegagalan bank di Indonesia, dengan menggunakan predikstor rasio CAMEL. Bank gagal terdiri dari bank dengan status BTO, BBO, bank rekap dan bank dalam pengawasan BPPN. Sebanyak 87 sampel bank diteliti Sampel sebanyak 87 bank periode tahun 1996 untuk memprediksi kondisi bank periode 1997 - 1998.

Penelitian Tengku Nuzulul Qurriyani (2000) menggunakan rasio-rasio CAMEL untuk menguji regulasi pemerintah dalam penentuan pailit atau tidaknya bank publik. Pada 19981999 telah terjadi pengkategorian 22 bank publik di Indonesia kedalam kategori BBO = 8 bank, BTO = 8 bank, dan tida pailit $=6$ bank. Dari 9 rasio yng dipilih melalui analisis faktor maka sebagai rasio predictor adalah kelompok rasio-rasio profitabilitas dan liquidity. Dari penggunaan analisis faktor dan model logit trikotomi diperoleh ketepatan pengkategorian keseluruhan $63,6 \%$ yang terdiri dari $75 \%$ kategori $\mathrm{BBO}, 50 \%$ dan bank tidak pailit $=66,7 \%$. Wilopo (2001) dalam penelitiannya menggunakan 13 rasio keuangan dari CAMEL, aset dan variabel dumy yaitu kredit lancar dan manajemen. Penelitian menghasilkan bahwa tingkat prediksi variabel yang digunakan cukup tinggi, tetapi memiliki tipe kesalahan untuk bank yang dilikuidasi 0\%. Haryati (2001) meneliti perbankan nasional yang diklasifikasikan dalam kategori A (memiliki CAR $\geq 4 \%$ ), kategori B $(4 \% \geq \mathrm{CAR} \geq-25 \%)$ dan kategori C (CAR $\leq-$ 25\%). Populasi penelitian meliputi 71 bank kategori A, 15 bank kategori B dan 9 bank kategori C. Hasil yang diperoleh adalah rasio efisiensi dan LDR tidak signifikan berpengaruh terhadap peluang kepailitan bank dan model yang dihasilkan mampu menghasilkan akurasi klasifikasi sebesar 73,5\%. Penelitian Hadad dkk (2004) tentang prediksi kepailitan bank umum di Indonesia. Metode analisis faktor dan regresi logistic yang digunakan, dengan variabel bebas adalah rasio modal dan resiko keuangan dengan variasi waktu sebagai variabel dummy dan variabel dependennya kepailitan bank. Hasil penelitian diperoleh bahwa model MP3 atau kondisi bank 3 bulan sebelum pailit lah yang layak digunakan sebagai model prediksi pada Bank Umum di Indonesia. Sedangkan tingkat akurasi yang dihasilkan adalah $94,9 \%$.

Penelitian ini akan membentuk model prediksi kepailitan dalam variasi waktu yaitu model prediksi 1 (satu) triwulan, 2 (dua) triwulan, 4 (empat) triwulan dan 8 (delapan) triwulan sebelum pailit. Pemilihan variasi waktu ini dengan pertimbangan untuk mengetahui lebih dini 
sinyal kepailitan yang mungkin terjadi dan rentang waktu triwulanan karena publikasi posisi laporan keuangan Bank Pekreditan Rakyat dilakukan dengan periode triwulan. Dengan dibentuknya model prediksi kepailitan dengan berbagai variasi waktu maka penelitian ini akan mencoba menemukan model prediksi dengan variasi waktu yang paling jauh sehingga bisa menjadi eraly warning system untuk kepailitan Bank Perkreditan Rakyat.

Penelitian ini memiliki kekhasan yang tidak terdapat pada penelitian-penelitian sebelumnya yaitu memunculkan model baru tentang prediksi kepailitan pada Bank Perkreditan Rakyat di Indonesia, yang dibentuk dari rasio rasio pada Earnings dan Liquidity. Menjadi sesuatu yang berbeda dan menarik untuk diteliti yaitu hal ini dilakukan pada Bank Perkreditan Rakyat di Indonesia yang masih belum banyak ditemukan tentang prediksi kepailitan pada Bank Perkreditan Rakyat di Indonesia. Hasil penelitian ini diharapkan dapat menjadi early warning system bagi manajemen Bank Perkreditan Rakyat di Indonesia.

\section{Return on Asssets}

Merupakan rasio yang sering digunakan untuk mengukur kinerja bank . ROA bergantung pada keampuan bank untuk memperoleh pendapatan bunga. ROA juga mengukur efisiensi penggunaan asset dalam menghasilkan laba (Indonesia, I.B., 2016).

\section{Return on Equity}

Merupakan suatu ukuran yang mempresentasikan kemampuan Bank Perkreditan Rakyat mempergunakan sumber daya yang dimiliki untuk menghasilkan laba atas ekuitas. Rasio ROE diperoleh dari perbandingan antara laba setelah pajak dengan rata-rata modal. Rata-rata modal dihitung dengan penjumlahan modal inti posisi Januari sampai dengan Desember kemudian dibagi 12 (Fahmi, I. ,2015).

\section{Net Interest Margin}

Merupakan pendapatan utama dari bank yang terdiri dari pendapatan bunga kredit, investasi dikurangi biaya dana deposito, tabungan dan sebagainya (Indonesia, I.B., 2016).

\section{Biaya Operasional Dibandingkan Pendapatan Operasional}

Menurut Veithzal (2013), rasio yang digunakan untuk mengukur tingkat efisiensi dan kemampuan bank dalam melakukan kegiatan operasinya. (Rivai, V., Basir, S., Sudarto, S., \& Veithzal, A. P. (2013).

\section{Loan to Deposits Ratio}

Memberikan indikasi bagaimana struktur deposit dari bank mendanai portofolio kredit bank. Semakin besar angka LDR artinya likuiditas bank semakin bergantung pada sumber dana non deposit (Indonesia, I.B., 2016). 
Penelitian yang berkesinambungan tentang kepailitan bank terutama Bank Perkreditan Rakyat menarik diteliti. Selanjutnya penelitian ini bertujuan menjawab pertanyaan permasalahan melalui pengujian hipotesis berikut:

Hipotesis 1: Berdasarkan rasio dalam earnings dan liquidity, bagaimanakah model prediksi kepailitan Bank Perkreditan Rakyat di Indonesia yang akurat?

Hipotesis 2: Model prediksi kepailitan berdasarkan variasi waktu manakah yang paling layak dan akurat untuk memprediksi kepailitan Bank Perkreditan Rakyat di Indonesia?

Hipotesis untuk menjawab pertanyaan dalam rumusan masalah ini sebagai berikut:

Hipotesis 1: Model prediksi kepailitan Bank Perkreditan Rakyat di Indonesia yang dibentuk dari rasio Earnings dan Liquidity akurat digunakan.

Hipotesis 2: Model prediksi kepailitan berdasarkan rasio Earnings dan Liquidity pada variasi waktu 1 (satu) triwulan sebelum pailit MP1 adalah model prediksi kepailitan Bank Perkreditan Rakyat di Indonesia yang paling layak dan akurat

Penelitian memiliki tujuan yaitu membentuk model prediksi kepailitan Bank Perkreditan Rakyat di Indonesia yang akurat menggunakan rasio dalam earnings dan liquidity. Dan menentukan model prediksi yang paling layak dan akurat untuk memprediksi kepailitan pada Bank Perkreditan Rakyat di Indonesia.

\section{METODE PENELITIAN}

Penelitian ini merupakan penelitian prediksi dengan menggunakan variabel prediktor terdiri dari rasio rasio Earningsi yaitu Return on Assets (ROA), Return on Equity (ROE), Net Interest Margin (NIM) dan Beban Operasional Pendapatan Operasional (BOPO) serta rasio Liquidity yaitu Loan to Deposit Ratio (LDR) akan digunakan untuk memprediksi kecenderungan pailit pada BPR di Indonesia. Didahului dengan membentuk model prediksi dilanjutkan menguji validasi model yang dihasilkan menggunakan data baru. Penelitian ini dirancang untuk menjelaskan kemampuan rasio rasio earnings dan liquidity dalam membentuk model prediksi kepailitan Bank Perkreditan Rakyat di Indonesia

Obyek penelitian ini adalah data rasio keuangan berupa Return on Assets (ROA), Return On Equity (ROE), Net Interest Margin (NIM) dan Beban Operasional Pendapatan Operasional (BOPO) dan Loan to Deposit Ratio (LDR) pada Bank Perkreditan Rakyat di Indonesia. Pertimbangan penentuan obyek penelitian ini sebagai berikut: Pertama, keberadaan dan kegiatan Bank Perkreditan Rakyat yang cukup. Kedua, persaingan antara Bank Perkreditan Rakyat di Indonesia dan lembaga keuangan lainnya yang cukup ketat untuk meraih 
kepercayaan masyarakat. Ketiga, tersedianya publikasi laporan keuangan Bank Perkreditan Rakyat untuk mendukung kebutuhan data penelitan.

Data berjenis data sekunder yang dipublikasikan di Otoritas Jasa Keuangan. Data diukur dalam skala rasio berupa data Return on Assets (ROA), Return on Equity (ROE), Net Interest Margin (NIM) dan Beban Operasional Pendapatan Operasional (BOPO) dan Loan to Deposit Ratio (LDR). Target populasi dalam penelitian ini adalah laporan keuangan seluruh Bank Perkreditan Rakyat di Indonesia sebanyak 1.668 Bank Perkreditan Rakyat dalam kategori sehat dan 93 Bank Perkreditan Rakyat dalam kategori bank pailit dengan rentang periode 2006 sampai dengan 2017. Pertimbangan penentuan populasi pada periode tersebut adalah: tahun 2006 sampai dengan 2017 adalah periode dimana jumlah Bank Perkreditan Rakyat di Indonesia yang dinyatakan pailit semakin meningkat; Bank Perkreditan Rakyat meskipun berskala kecil tetapi sebagian besar nasabahnya adalah kalangan masyarakat kecil dan mikro sehingga keberadaan mereka juga perlu diperhatikan.

Bank Perkreditan Rakyat yang menjadi sampel dikelompokkan menjadi 2, yaitu Bank Perkreditan Rakyat yang pailit dan Bank Perkreditan Rakyat yang tidak pailit. Teknik sampel menggunakan purposive sampling. Bank Perkreditan Rakyat yang pailit adalah Bank Perkreditan Rakyat yang memiliki kriteria sebagai berikut: Bank Perkreditan Rakyat konvensional di Indonesia; Bank Perkreditan Rakyat di Indonesia yang dinyatakan pailit pada rentang periode 2006 sampai dengan 2017; Aktif publikasi laporan keuangan sebelum dinyatakan pailit di direktori Otoritas jasa Keuangan; Memiliki kelengkapan laporan keuangan yang dibutuhkan yaitu laporan neraca, laporan laba rugi dan laporan informasi lainnya. Bank pada kelompok Bank Perkreditan Rakyat tidak pailit memiliki kriteria sebagai berikut : Bank Perkreditan Rakyat konvensional di Indonesia; Bank Perkreditan Rakyat di Indonesia yang masih beroperasi dan aktif publikasi laporan keuangannya di direktori Otoritas jasa Keuangan; Memiliki laporan keuangan yang lengkap. Berdasarkan kriteria sampel yang ditentukan maka diperoleh sampel Bank Perkreditan Rakyat yang pailit sebanyak 29 Bank Perkreditan Rakyat dan 200 bank Perkreditan Rakyat yang tidak pailit.

Data sampel penelitian dibagi menjadi 2 (dua) kelompok yaitu design subsample dan validation subsample. Merujuk pada Sumarno (1994), yang dimaksud design sample adalah sampel untuk membangun model prediksi. Adapun validation sample adalah sampel yang digunakan dalam melakukan uji validasi terhadap model prediksi yang dihasilkan dari design sample. Data yang digunakan untuk design sample adalah data laporan keuangan triwulanan Bank Perkreditan Rakyat di Indonesia periode 2006 sampai dengan 2016, sedangkan untuk 
validation sample adalah data laporan keuangan triwulanan Bank Perkreditan Rakyat di Indonesia periode 2017.

Menurut Sumarno (1994:23), suatu model seharusnya dievaluasi dengan menguji akurasi prediksinya berdasarkan design dan validation sample. Selama data yang digunakan untuk akurasi validasi berbeda dengan data yang digunakan untuk membentuk fungsi klasifikasi (atau prediksi) maka error rate yang diperoleh adalah unbiased (Rencher, 1995:337). Menurut (Hair, Anderson, Tatham, and Black, 1998), tidak ada acuan pasti dalam membagi sampel menjadi kelompok analisis dan kelompok validasi. Para peneliti menyukai pembagian 60 - 40 atau 75 - 25 antara kelompok analisis dan kelompok validasi. Selain itu sample size untuk masing-masing sifat dikotomi (failed-nonfailed) variabel dependen besarnya tidak selalu harus sama. Variabel independen $\left(\mathrm{X}_{\mathrm{i}}\right)$ sebagai variabel berupa rasio earnings dan liquidity.. Adapun variabel independen memiliki ukuran skala rasio yang terdiri dari:

$\mathrm{X}_{1}$ : Return on Assets (ROA)

$\mathrm{X}_{2}$ : Return on Equity (ROE)

$\mathrm{X}_{3}:$ Net Interest Margin (NIM)

$\mathrm{X}_{4}$ : Beban Operasional Pendapatan Operasional (BOPO)

$\mathrm{X}_{5}$ : Liquidity

Variabel dependen adalah status kepailitan BPR di Indonesia yang pailit dan tidak pailit. Penggunaan variasi waktu berupa laporan keuangan Bank Perkreditan Rakyat pada 1 triwulan, 2 triwulan, 4 triwulan dan 8 triwulan sebelum pailit dengan maksud untuk menentukan variasi waktu yang tepat untuk memprediksi kepailitan. Tenik analisis data menggunakan analisis regresi logistik (logistic regression) digunakan sebagai tehnik analisis data dimana masing-masing model prediksi dalam penelitian ini dolah dengan urutan sebagai berikut:

Membangun model prediksi kepailitan, model prediksi dibangun berdasarkan model regresi logistik diformulasikan oleh persamaan sebagai berikut:

$$
P_{i}=E(Y=1) X_{i, t-k}=\frac{1}{\left.1+e^{-\beta_{0}}+\sum_{k j=1}^{j} \beta_{1} X_{i j, t-k}\right)}
$$

Atau

$$
\left.P_{i}=\frac{1}{1+e^{-2 t}} \text { dan } Z_{i t}=-\beta_{0}+\sum_{k j=1}^{j} \beta_{1} X_{i j, t-k}\right)
$$


dimana:

$\mathrm{P} i \quad$ : peluang BPR ke-i pailit

Xij : prediktor j untuk BPR ke-i

$\mathrm{Z}_{\mathrm{i}} \quad$ : fungsi linier dari variabel prediktor $;-$ oo $\leq \mathrm{Z}_{\mathrm{i}} \leq+$ oo

t $\quad$ : saat BPR pailit

$\mathrm{k} \quad$ : periode sebelum BPR pailit

$e \quad: \log$ natural $; e=2,71828$

$\beta \quad$ : koef regresi

Selanjutnya persamaan disesuaikan dengan memasukkan variabel $\mathrm{X}_{\mathrm{T}}$ (variasi waktu). Kelompok variasi waktu terdiri dari 4 kelompok periode sebelum pailit, yaitu 1 triwulan, 2 triwulan, 4 triwulan dan 8 triwulan sebelum pailit, maka banyaknya variabel dummy adalah D $=\mathrm{k}-1=4-1=3$. Variabel dummy variasi waktu $\left(\mathrm{X}_{\mathrm{T}}\right)$ dimasukkan dalam persamaan menjadi:

$$
\left.P_{i}=\frac{1}{1+e^{-Z t}} \text { dan } Z_{t}=\beta_{0}+\beta_{i} D_{i}+\sum_{p=1}^{m} \beta_{p} \beta_{p}\right)+1+f_{p}
$$

dimana:

f : faktor, sebagai variabel independen

$\mathrm{D}=\mathrm{X}_{\mathrm{T}}$ : variabel dummy variasi waktu, untuk $\mathrm{i}=1,2,3,4$.

$\mathrm{p} \quad$ : jumlah faktor dalam satu kelompok, untuk $\mathrm{p}=1,2, \ldots, \mathrm{m}$

$\beta \quad$ : koefisien regresi

Persamaan ini selanjutnya akan dipergunakan untuk membentuk model prediksi kepailitan pada variasi waktu 1 triwulan, 2 triwulan, 4 triwulan dan 8 triwulan sebelum pailit. Selanjutnya untuk mengetahui seberapa baik hasil regresi logistik maka sebagai langkah verifikatif dilakukan beberapa langkah pengujian terhadap persamaan sebagai berikut (Stock \& Watson, 2007, dalam Widarjono, 2015:112) seperti : Goodness of Fit $R^{2}$, Uji Signifikansi Serentak (Overall Model Fit), Uji Signifikansi individu (Wald Statistic) dan Odds Ratio.

Goodness of fit digunakan untuk mengetahui kebaikan model prediksi dengan menggunakan ukuran Hosmer and Lemeshow untuk menilai ketidaksamaan antara nilai pengamatan dan nilai prediksi. Semakin kecil ketidaksamaan diantara keduanya maka model yang diperoleh semakin baik (Hair et.al, 1998: 318). Menggunakan kriteria berikut: Jika nilai 
sig $>\alpha$, maka model dikatakan fit dan Jika nilai sig $<\alpha$, maka model dikatakan tidak fit. Selain itu juga untuk mengetahui kebaikan model prediksi, digunakan ukuran Pseudo $R^{2}$ yang sering digunakan dalam model logit yaitu Pseudo $R^{2}$ Cox and Snell dan Pseudo ${ }^{2}$ Nagelkerke. Cox and Snell $R^{2}$ memiliki kelemahan yaitu nilainya tidak pernah mendekati 1, sehingga selanjutnya dilakukan modifikasi model dengan menggunakan Nagelkerke $R^{2}$. Kriteria yang digunakan adalah besarnya nilai $R^{2}$ menunjukkan semakin baik model prediksi yang dihasilkan.

Uji Signifikansi Serentak (Overall Model Fit), penggunaan Overall Model Fit untuk mengetahui pengaruh secara serentak semua variabel bebas dalam model prediksi terhadap variabel terikat. Uji signifikansi serentak dengan nilai Chi Square $\left(R^{2}\right)$. Hipotesis untuk menilai uji signifikansi serentak dengan menggunakan Ho: tidak berpengaruh signifikan secara simultan dan $\mathrm{H}_{1}$ : berpengaruh signifikan secara simultan. Kriteria yang digunakan: Jika $\left(R^{2}\right)$ hitung $<\left(R^{2}\right)$ tabel, maka Ho diterima dan Jika $\left(R^{2}\right)$ hitung $>\left(R^{2}\right)$ tabel, maka Ho ditolak.

Uji Signifikansi individu (Wald Statistic) dan Odds Ratio,Uji signifikansi Individu digunakan untuk menguji pengaruh individu antar variabel. Kriteria yang digunakan: Jika nilai sig $>\alpha$, maka tidak terdapat pengaruh individu dan Jika nilai $\operatorname{sig}<\alpha$, maka terdapat pengaruh individu. Kemudian Odds Ratio yang merupakan nilai nilai Exp (B) untuk memperoleh seberapa besar variabel prediktor cenderung mempengaruhi kepailitan bank Perkreditan Rakyat.

Selanjutnya untuk membuktikan bahwa model prediksi kepailitan Bank Perkreditan Rakyat yang dihasilkan terbukti akurat maka dilakukan analisis Power of Regression to Predict. Pengujian power of regression to predict merupakan kemampuan untuk memprediksi kekuatan model prediksi peluang Bank Perkreditan Rakyat terjadi pailit atau tidak. Model prediksi memberikan skor dengan rentang 0 sampai 1 sebagai probabilitas. Cut-off-point adalah nilai untuk menentukan sebuah Bank Perkreditan Rakyat diestimasikan sebagai Bank Perkreditan Rakyat yang pailit atau tidak pailit. Nilai cut-off-point ditunjukkan oleh correct estimates, semakin tinggi nilai correct estimates maka semakin kuat daya ramal model prediksi yang dibentuk dan sebaliknya.

Penelitian ini memiliki keunggulan yaitu disamping memberikan output model prediksi kepailitan juga melakukan penilaian kinerja model prediksi kepailitan yang dibentuk dari sampel desain. Sumarno (1994:23), sebuah model seharusnya diuji akurasi prediksinya berdasarkan sampel desain dan validasi. Jika data untuk akurasi validasi tidak sama dengan data untuk membentuk fungsi klasifikasi maka error rate yang diperoleh adalah unbiased 
(Rencher, 1995:337). Beberapa studi tentang kepailitan bank sebelumnya tidak semuanya melakukan uji validasi atas model prediksi. Kinerja model prediksi perlu dilakukan penilaian sebagai prasyarat jika tujuan penelitian adalah memprediksi suatu kejadoan atau peluang, yaitu dengan melakukan komparasi empiris (Beaver, Kennelly, \& Voss, 1968). Menurut Sumarno (1994:50), umumnya metode akurasi klasifikasi baik pada desain maupun sampel validasi digunakan untuk uji model dalam penelitian failure prediction.

\section{HASIL DAN PEMBAHASAN}

Model prediksi kepailitan Bank Perkreditan Rakyat di Indonesia ini dibangun berdasarkan prediktor yang berupa rasio rasio earnings dan liquidity yang terdiri dari ROA, ROE, NIM dan BOPO untuk 4 (empat) variasi waktu yaitu 1 triwulan, 2 triwulan, 4 triwulan dan 8 triwulan sebelum pailit yang selajutnya disingkat dengan MP1, MP2, MP4 dan MP8. Dengan menggunakan analisis regresi logistik maka diperoleh model prediksi kepailitan Bank Perkreditan Rakyat di Indonesia pada 4 (empat) variasi waktu sebagai berikut:

\section{Model Kepailitan 1 Triwulan Sebelum Pailit (MP1)}

Model prediksi kepailitan MP1 dibentuk dari data 1 triwulan sebelum pailit, hasil komputasi regresi logistik menghasilkan model prediksi sebagai berikut:

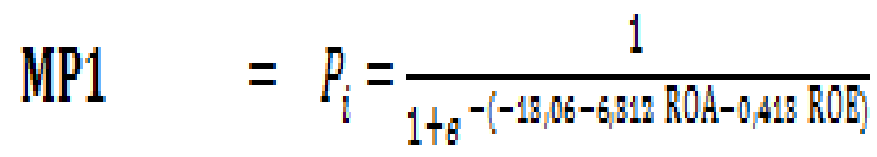

ROA memiliki signifikan 0,987 dengan nilai Exp (B) sebesar 0,002 yang berarti ROA cenderung mempengaruhi kepailitan Bank Perkreditan Rakyat sebesar 0,002. Sedangkan ROE memiliki signifikan 0,990 dengan nilai Exp (B) sebesar 0,662 yang berarti ROE cenderung mempengaruhi kepailitan Bank Perkreditan Rakyat sebesar 0,662. Hasil goodness of fit test menggunakan uji Hosmer and Lemeshow menunjukkan bahwa MP1 memiliki nilai probabilitas $\operatorname{sig}=1,000$. Oleh karena nilai sig $(1,000)>\alpha(0,05)$, maka $\mathrm{H}_{1}$ ditolak dan Ho diterima maka kesimpulannya klasifikasi Bank Perkreditan Rakyat pailit dan tidak pailit yang diprediksi persamaan MP1 sama signifikan dengan $\alpha=5 \%$ pada klasifikasi Bank Perkreditan Rakyat pailit dan tidak pailit yang diamati. Dengan demikian persamaan MP1 dinyatakan sebagai model regresi yang fit atau layak digunakan karena model yang dihasilkan dapat memprediksi nilai pengamatannya. Diukur dengan nilai $R^{2}$ Cox and Snell dan $R^{2}$ Nagelkerke MP1 memiliki nilai 0,594 dimana variabel dependen variasinya dijelaskan sebesar 59,4\%.

Selanjutnya dilakukan uji signifikansi serentak Overall Model Fit untuk menilai apakah variabel independen dalam model prediksi secara serentak berpengaruh terhadap 
variabel dependen. Dihasilkan nilai chi square 108,135 dengan sig 0,000 maka kesimpulannya variabel independen secara serentak mempengaruhi variabel dependen. Sedangkan untuk uji signifikansi individu diperoleh nilai signifikansi ROA (sig.0,987) dan nilai signifikansi ROE (sig.0,990) yang keduanya berada diatas sig.0,05 ( sig > 0,05) maka ROA dan ROE secara individu tidak berpengaruh signifikan terhadap variabel dependen.

Dengan cut-off sebesar 0,20 yang merupakan proporsi antara jumlah Bank Perkreditan Rakyat pailit dengan Bank Perkreditan Rakyat tidak pailit pada data sampel desain yaitu 20 Bank Perkreditan Rakyat pailit dibandingkan 100 Bank Perkreditan Rakyat tidak pailit, secara keseluruhan MP1 terbukti mampu mengklasifikasikan 120 Bank Perkreditan Rakyat yang diobservasi dengan tingkat akurasi 100\%. Oleh karena itu dengan tingkat akurasi $100 \%$ maka MP1 dinilai memiliki kinerja yang baik.

\section{Model Kepailitan 2 Triwulan Sebelum Pailit (MP2)}

Model prediksi kepailitan MP2 dibentuk dari data 2 triwulan sebelum pailit, hasil komputasi regresi logistik menghasilkan model prediksi sebagai berikut:

$\mathrm{MP2}=P_{i}=\frac{1}{1+\theta^{-(-12 ; 549-2 ; 856 \mathrm{ROE})}}$

ROE memiliki signifikan 0,966 dengan nilai Exp (B) sebesar 0,058 yang berarti ROE cenderung mempengaruhi kepailitan Bank Perkreditan Rakyat sebesar 0,058. Hasil goodness of fit test yang diukur dengan uji Hosmer and Lemeshow menunjukkan bahwa MP2 memiliki nilai probabilitas sig $=1,000$. Oleh karena nilai sig $(1,000)>\alpha(0,05)$, maka kesimpulannya klasifikasi Bank Perkreditan Rakyat pailit dan tidak pailit yang diprediksi persamaan MP2 tidak berbeda secara signifikan pada $\alpha=5 \%$ dengan klasifikasi Bank Perkreditan Rakyat pailit dan tidak pailit yang diamati. Dengan demikian persamaan MP2 dinyatakan sebagai model regresi yang fit atau layak digunakan karena model yang dihasilkan dapat memprediksi nilai observasinya. Diukur dengan nilai $R^{2}$ Cox and Snell dan $R^{2}$ Nagelkerke MP2 memiliki nilai 0,594 yang berarti variabilitas variabel dependen yang dapat dijelaskan oleh variabilitas variabel independen sebesar 59,4\%.

Selanjutnya dilakukan uji signifikansi serentak Overall Model Fit dan diperoleh nilai chi square sebesar 108,135 dengan sig 0,000 maka kesimpulannya semua variabel independen dalam model prediksi secara serentak mempengaruhi variabel dependen. Sedangkan untuk uji signifikansi individu diperoleh nilai signifikansi ROE (sig.0,966) maka dapat disimpulkan bahwa ROE secara individu tidak berpengaruh signifikan terhadap variabel dependen. Dengan cut-off sebesar 0,20, secara keseluruhan MP2 terbukti mampu mengklasifikasikan 120 Bank 
Perkreditan Rakyat yang diobservasi dengan tingkat akurasi 100\%. Atas dasar persentase akurasi ini maka MP2 dinilai memiliki kinerja yang baik.

\section{Model Kepailitan 4 Triwulan Sebelum Pailit (MP4)}

Model prediksi kepailitan MP4 dibentuk dari data 4 triwulan sebelum pailit, hasil komputasi regresi logistik menghasilkan model prediksi sebagai berikut:

MP4 $\quad=P_{i}=\frac{1}{\left.1+\theta^{-(-4,178-0,067} \mathrm{ROA}+0,042 \mathrm{LDR}\right)}$

ROA memiliki signifikan 0,001 dengan nilai Exp (B) sebesar 0,545 yang berarti ROA cenderung mempengaruhi kepailitan Bank Perkreditan Rakyat sebesar 0,545. Sedangkan LDR memiliki signifikan 0,045 dengan nilai Exp (B) sebesar 1,043 yang berarti LDR cenderung mempengaruhi kepailitan Bank Perkreditan Rakyat sebesar 1,043. Hasil goodness of fit test yang diukur dengan uji Hosmer and Lemeshow menunjukkan bahwa MP4 memiliki nilai probabilitas sig $=0,358$. Oleh karena nilai sig $(0,358)>\alpha(0,05)$, maka kesimpulannya klasifikasi Bank Perkreditan Rakyat pailit dan tidak pailit yang diprediksi persamaan MP4 tidak berbeda secara signifikan pada $\alpha=5 \%$ dengan klasifikasi Bank Perkreditan Rakyat pailit dan tidak pailit yang diamati. Dengan demikian persamaan MP4 dinyatakan sebagai model regresi yang fit atau layak digunakan karena model yang dihasilkan dapat memprediksi nilai observasinya. Diukur dengan nilai $R^{2}$ Cox and Snell dan $R^{2}$ Nagelkerke MP4 memiliki nilai 0,385 yang berarti variabilitas variabel dependen yang dapat dijelaskan oleh variabilitas variabel independen sebesar $38,5 \%$.

Selanjutnya dilakukan uji signifikansi serentak Overall Model Fit dan diperoleh nilai chi square sebesar 58,298 dengan sig 0,000 maka kesimpulannya semua variabel independen dalam model prediksi secara serentak mempengaruhi variabel dependen. Sedangkan untuk uji signifikansi individu diperoleh nilai signifikansi ROA (sig.0,001) dan nilai signifikansi LDR (sig.0,045) yang keduanya berada dibawah sig.0,05 ( sig < 0,05) maka dapat disimpulkan bahwa ROA dan LDR secara individu berpengaruh signifikan terhadap variabel dependen. Dengan cut-off sebesar 0,20, secara keseluruhan MP4 terbukti mampu mengklasifikasikan 120 Bank Perkreditan Rakyat yang diobservasi dengan tingkat akurasi 89,2\%. Atas dasar persentase akurasi ini maka MP4 dinilai memiliki kinerja yang baik.

\section{Model Kepailitan 8 Triwulan Sebelum Pailit (MP8)}

Model prediksi kepailitan MP8 dibentuk dari data 8 triwulan sebelum pailit, hasil komputasi regresi logistik menghasilkan model prediksi sebagai berikut:

MP8 $\quad=P_{i}=\frac{1}{1+8-(-14,494+0,152 \mathrm{BOPO})}$ 
BOPO memiliki signifikan 0,000 dengan nilai Exp (B) sebesar 1,164 yang berarti BOPO cenderung mempengaruhi kepailitan Bank Perkreditan Rakyat sebesar 1,164. Hasil goodness of fit test yang diukur dengan uji Hosmer and Lemeshow menunjukkan bahwa MP8 memiliki nilai probabilitas sig $=0,201$. Oleh karena nilai sig $(0,201)>\alpha(0,05)$, maka kesimpulannya klasifikasi Bank Perkreditan Rakyat pailit dan tidak pailit yang diprediksi persamaan MP8 tidak berbeda secara signifikan pada $\alpha=5 \%$ dengan klasifikasi Bank Perkreditan Rakyat pailit dan tidak pailit yang diamati. Dengan demikian persamaan MP8 dinyatakan sebagai model regresi yang fit atau layak digunakan karena model yang dihasilkan dapat memprediksi nilai observasinya. Diukur dengan nilai $R^{2}$ Cox and Snell dan $R^{2}$ Nagelkerke MP8 memiliki nilai 0,337 yang berarti variabilitas variabel dependen yang dapat dijelaskan oleh variabilitas variabel independen sebesar 33,7\%.

Selanjutnya dilakukan uji signifikansi serentak Overall Model Fit dan diperoleh nilai chi square sebesar 49,233 dengan sig 0,000 maka kesimpulannya semua variabel independen dalam model prediksi secara serentak mempengaruhi variabel dependen. Sedangkan untuk uji signifikansi individu diperoleh nilai signifikansi BOPO (sig.0,000) yang berada dibawah sig.0,05 ( sig < 0,05) maka dapat disimpulkan bahwa BOPO secara individu berpengaruh signifikan terhadap variabel dependen. Dengan cut-off sebesar 0,20, secara keseluruhan MP8 terbukti mampu mengklasifikasikan 120 Bank Perkreditan Rakyat yang diobservasi dengan tingkat akurasi 85,8\%. Atas dasar persentase akurasi ini maka MP8 dinilai memiliki kinerja yang baik.

\section{Mengukur Akurasi Model atau Validasi Model}

Tahap ini dilakukan dengan mengukur akurasi model persamaan pada masing-masing model prediksi yaitu persamaan model regresi MP1, MP2, MP4 dan MP8, dengan menggunakan data validasi pada tahun 2017 sebanyak 109 Bank Perkreditan Rakyat terdiri dari 9 Bank Perkreditan Rakyat pailit dan 100 Bank Perkreditan Rakyat tidak pailit pada masing-masing model. Penggunaan tabel akurasi klasifikasi tetap digunakan untuk mengukur akurasi model persamaan dimaksud. Diperoleh nilai cut-off sebesar 0,09 yang merupakan proporsi antara jumlah Bank Perkreditan Rakyat pailit dengan Bank Perkreditan Rakyat tidak pailit pada data sampel validasi yaitu 9 Bank Perkreditan Rakyat pailit dibandingkan 100 Bank Perkreditan Rakyat tidak pailit. Oleh karena itu jika Bank Perkreditan Rakyat memiliki probabilitas diatas 0,09 (prob > 0,09) maka Bank Perkreditan Rakyat tersebut diprediksikan kedalam klasifikasi Bank Perkreditan Rakyat pailit. Sebaliknya jika Bank Perkreditan Rakyat memiliki probabilitas dibawah 0,09 (Prob < 0,09) maka Bank Perkreditan Rakyat tersebut 
diprediksikan kedalam klasifikasi Bank Perkreditan Rakyat tidak pailit. Ketepatan mengklasifikasikan digunakan untuk mengukur kinerja model yang dihasilkan.

Perbandingan hasil model prediksi kepailitan Bank Perkreditan Rakyat di Indonesia berdasarkan data sampel desain dan sampel validasi pada masing-masing variasi waktu model yaitu MP1, MP2, MP4 dan MP8 disajikan pada tabel sebagai berikut:

Tabel 1. Model Prediksi Kepailitan Bank Perkreditan Rakyat di Indonesia

\begin{tabular}{ccccc}
\hline Keterangan & MP 1 & MP 2 & MP 4 & MP 8 \\
\hline Sampel desain : & \multicolumn{3}{c}{ Permodelan } \\
BPR pailit & 20 & 20 & 20 & 20 \\
BPR tidak pailit & 100 & 100 & 100 & 100 \\
Cut-off Point & 0,20 & 0,20 & 0,20 & 0,20 \\
Correct Estimates (\%) & 100,0 & 100,0 & 89,2 & 85,8 \\
\hline
\end{tabular}

Uji Validasi

Sampel desain :

BPR pailit

BPR tidak pailit

Cut-off Point

Correct Estimates (\%)
9

100

0,09

90,83
9

100

0,09

92,66
9

100

0,09

91,74
9

100

0,09

20,18

Sumber : Data diolah dari Direktori Otoritas Jasa Keuangan, 2020

Setelah diuji akurasi model prediksi pada masing masing model dengan menggunakan data sampel validasi, maka diperoleh bahwa MP2 memiliki kemampuan mengklasifikasikan dengan tingkat keakuratan yang paling tinggi yaitu 92,66\%. Namun demikian meskipun pada sampel permodelan MP 1 da MP 2 memiliki kemampuan mengklasifikasikan yang tinggi yaitu 100\% dan pada sampel validasi juga memiliki keakuratan yang tinggi yaitu 90,83\% dan 92,66\%, namun MP1 dan MP2 tidak bisa dipilih sebagai model prediksi yang baik karena secara individual kedua model tersebut tidak berpengaruh signifikan. Oleh karena itu MP4 dipilih sebagai model prediksi yang akurat dan baik karena disamping memiliki tingkat keakuratan yang tinggi yaitu 91,74\% juga secara serentak dan individual juga berpengaruh signifikan sebagai prediktor kepailitan.

Rasio rasio earnings dan liquidity terbukti dapat digunakan sebagai predictor kepailitan Bank Perkreditan Rakyat di Indonesia. Rasio earnings yang terdiri dari ROA, ROE, NIM dan BOPO serta rasio liquidity yang terdiri dari LDR terbukti mampu menjadi prediktor 
kepailitan dengan tepat pada keempat model prediksi yaitu MP1, MP2, MP4 dan MP8. Penelitian yang sejalan telah dilakukan oleh Martin (1977), Qurriyani T. N. (2000), Wilopo (2001), Haryati (2001) dan Hadad, dkk (2004) bahwa rasio rasio keuangan perbankan CAMEL dapat menjadi prediktor kepailitan bank.

Sementara itu MP4 dipilih sebagai model prediksi kepailitan yang paling akurat karena memiliki tingkat keakuratan yang tinggi dan memiliki kinerja yang paling baik diantara keempat model prediksi. Mp 4 dibentuk dari rasio ROA dengan arah negatif dan LDR dengan arah positif. Hal ini berarti jika ROA tinggi maka peluang bank akan mengalami kepailitan rendah dan sebaliknya. Sedangkan jika LDR tinggi maka semakin besar juga peluang bank akan mengalami kepailitan. Jika kemampuan bank dalam meraih laba meningkat maka bank tersebut akan dalam kondisi aman atau peluangnya mengalami kepailitan juga semakin rendah karena dengan keuntungan yang semakin meningkat maka bank akn mampu menjaga keberlanjutannya menjadi lebih baik. Sementara itu jika LDR meningkat maka peluang bank mengalami kepailitan juga ikut meningkat. Hal ini disebabkan karena dengan tingginya LDR menunjukkan bahwa kredit yang berhasil disalurakn ke masyarakat juga tinggi. Tingginya dana bank yang beredar ke masyarakt dalam bentuk kredit disampng menguntungkan tetapi juga mengandung risiko yang tinggi juga. Oleh karena itu jika jumlah uang yang disalurkan dalam betuk kredit ke masyarakat semakin besar maka kan semakin tinggi juga risikonya yang juga bisa berakibat meningkatnya peluang bank mengalami kepailitan. Temuan teoritis bahwa model prediksi yang dihasilkan sejalan Agency Theory (Jensen dan Meckling, 1976) bahwa hubungan keagenan merupakan suatu kontrak dimana satu atau lebih orang (principal) memerintah orang lain (agen) untuk melakukan suatu jasa atas nama prinsipal serta memberi wewenang kepada agen membuat keputusan yang terbaik bagi principal.

\section{KESIMPULAN DAN SARAN}

Model prediksi kepailitan Bank Perkreditan Rakyat di Indonesia dibentuk dari rasio rasio earnings dan liquidity yang terdiri dari rasio ROA, ROE, NIM, BOPO dan LDR. Model prediksi kepailitan Bank Perkreditan Rakyat di Indonesia dengan rasio earnings dan liquidity disusun berdasarkan 4 (empat) variasi waktu yaitu 1 triwulan, 2 triwulan, 4 triwulan dan 8 triwulan sebelum pailit yang selanjutnya disingkat MP1, MP2, MP4 dan MP8. Model prediksi 4 triwulan atau MP4 dipilih sebagai model prediksi yang paling layak dan akurat digunakan yang dibentuk dari prediktor ROA dan LDR karena memiliki tingkat keakuratan yang paling tinggi baik pada permodelan maupun saat diuji dengan sampel validasi. 
Model prediksi kepailitan BPR di Indonesia ini dapat digunakan sebagai solusi deteksi dini oleh pihak manajemen BPR, untuk mendeteksi apakah BPR mempunyai tanda pailit atau tidak. MP4 yang dibentuk oleh rasio ROA dan LDR akan sangat membantu pihak manajemen Bank Perkreditan Rakyat untuk menentukan strategi dalam menghadapi persaingan antar lembaga keuangan bank dan non bank, yaitu dengan mengutamakan mengatur portofolio dana bank dan portofolio kredit dengan menerapkan prinsip prudential banking.

Model prediksi kepilitan ini dapat digunakan sebagai pertimbangan dalam menjalankan fungsi pengawasan dan pembinaan terhadap Bank Perkreditan Rakyat yang beroperasi di Indonesia bahwa untuk lebih optimal dalam menjaga portofolio kreditnya sejak dini yaitu sejak kredit dicairkan dan bahkan agar bisa melakukan tindakan preventif dengan memberikan kredit yang sehat dengan prinsip kehati hatian yang tinggi meskipun dituntut untuk tetap dapat memiliki daya saing.

Tidak dapat dipungkiri bahwa penelitian ini juga memiliki kelemahan dan keterbatasan, namun keterbatasan yang ada dapat digunakan untuk perbaikan dan rujukan penelitian mendatang, yaitu penelitian ini hanya menggunakan data Bank Perkreditan Rakyat yang berprinsip konvensional, oleh karena itu perlu dipertimbangkan untuk melakukan penelitian pada Bank Perkreditan Rakyat yang berprinsip syariah karena dengan prinsip yang berbeda maka ada kemungkinan bisa menghasilkan model prediksi yang berbeda bagi Bank Perkreditan Rakyat di Indonesia. Untuk peneliti yang ingin melakukan penelitian tentang prediksi kepailitan bank dianjurkan untuk meneliti Bank Pembiayaan Rakyat yang berprinsip syariah karena dengan prinsip yang berbeda maka ada kemungkinan bisa menghasilkan model prediksi yang berbeda bagi Bank Perkreditan Rakyat di Indonesia. Perlu juga dipertimbangkan untuk menggunakan Manajemen Risiko dalam POJK nomor 13/POJK.03/2015 tentang Penerapan Manajemen Risiko bagi BPR.

\section{REFERENSI}

Beaver, W. H., Kennelly, J. W., \& Voss, W. M. (1968). Predictive Ability as a Criterion for The Evaluation of Accounting Data. The Accounting Review, 43(4), 675-683.

Fahmi, I. (2015). Manajemen Perbankan Konvensional dan Syariah. Jakarta: Mitra Wacana Media.

Hadad, M. D., Santoso, W., Sarwedi, H. S., \& Adenan, M. (2004). Model Prediksi Kepailitan Bank Umum di Indonesia. Bank Indonesia Research Paper, Direktorat Penelitian Dan Peraturan Perbankan Bank Indonesia.

Hair, J. F., Anderson, R. E., Tatham, R. L., \& Black, W. C. (1998). Multivariate Data Analysis. Englewood Cliff. New Jersey, USA, 5(3), 207-2019.

Haryati, S. (2001).Analisis Kebangkrutan Bank. Journal of Indonesian Economy and Business, 16(4). 
Krause, L. M., Schindler, A., Linkous, D. H., Cooper, D. S., Flinn, J. M., \& Jones, B. F. (2001). The Effect of Enhanced Levels of Zinc on Spatial Memory and Brain Function in Rats. In Soc Neurosci Meeting (Abstr) (Vol. 27, p. 15).

Indonesia, G. B. (2004). Peraturan Bank Indonesia Nomor: 6/10/PBI/2004 tentang Sistem Penilaian Tingkat Kesehatan Bank Umum. Peraturan Bank Indonesia.

Indonesia, I. B. (2016). Manajemen Kesehatan Bank Berbasis Risiko. Gramedia Pustaka Utama.

Martin, D. (1977). Early Warning of Bank Failure: A Logit Regression Approach. Journal of Banking \& Finance, 1(3), 249-276.

Mongid, A. (2000). Accounting Data and Bank Future Failure: A Model For Indonesia. Simposium Nasional Akuntansi.

Otoritas Jasa Keuangan. (2015). Peraturan Otoritas Jasa Keuangan Nomor 13/POJK.03/2015 tentang Penerapan Manajemen Risiko Bank Perkreditan Rakyat. Jakarta.

Komisioner D, Jasa O. Manajemen Risiko Bank Perkreditan Rakyat.Otoritas Jasa Keuangan Republik Indonesia. 2015.

Qurriyani, T. N. (2000). Indikasi Potesial Menuju Bank Survival Melalui Analisis Rasio Keuangan: Model Regresi Logistik Trikotomi. SimposiumNasional Akuntansi III, September, IAI, Hlm, 619-651.

Rencher, A. C. (1995). Methods of Multivariate Analysis. John wiley\&son. Inc. Publication, Canada, 380-407.

Rivai, V., Basir, S., Sudarto, S., \& Veithzal, A. P. (2013). Commercial Bank Management: Manajemen Perbankan dari Teori ke Praktik. Jakarta: Rajawali Pers.

Santoso, W. (1996). The Determinants of Problem Banks in Indonesia. Banking Research and Regulation Paper, Bank Indonesia.

Scott, W. R. (2015). Financial Accounting Theory Seventh Edition. United States: Canada Cataloguing.

Sumarno, Z. (1994). Failure Prediction: an Artificial Intelligence Approach. Ghent University.

Widarjono, A. (2015). Analisis Multivariat Terapan. Yogyakarta: UPP STIM YKPN.

Wilopo. (2001). Prediksi Kebangkrutan Bank. Jurnal Riset Akuntansi Indonesia. Vol. 4. No. 2. p $184-198$.

Zain, Sumarno. (1994). Failure Prediction: An Artificial Intelligence Approach, Accountancy Development in Indonesia. Publication No.21. Tim Koordinasi Pengembangan Akuntansi. Jakarta. 